\title{
Assessment of the anti-pathogenic effects of condensed tannin extracts using scanning electron microscopy
}

Article

Accepted Version

Dakheel, M. M. ORCID: https://orcid.org/0000-0002-19388098, Kaur, A., Al-Mnaser, A. A., Mueller-Harvey, I., Woodward, M. J. and Rymer, C. (2021) Assessment of the anti-pathogenic effects of condensed tannin extracts using scanning electron microscopy. Archives of Microbiology, 203. pp. 1555-1563. ISSN 0302-8933 doi:

https://doi.org/10.1007/s00203-020-02147-9 Available at https://centaur.reading.ac.uk/95545/

It is advisable to refer to the publisher's version if you intend to cite from the work. See Guidance on citing.

To link to this article DOI: http://dx.doi.org/10.1007/s00203-020-02147-9

Publisher: Springer

All outputs in CentAUR are protected by Intellectual Property Rights law, including copyright law. Copyright and IPR is retained by the creators or other copyright holders. Terms and conditions for use of this material are defined in the End User Agreement. 


\section{CentAUR}

Central Archive at the University of Reading

Reading's research outputs online 


\title{
Assessment of the anti-pathogenic effects of condensed tannin extracts using scanning electron microscopy
}

Mohammed M. Dakheel ${ }^{1^{*}}$, Amanpreet Kaur², Afnan A. Al- Mnaser ${ }^{3}$, Irene Mueller-Harvey ${ }^{4}$, Martin J. Woodward $^{3}$ and Caroline Rymer ${ }^{4^{*}}$

1 Department of Veterinary Public Health, College of Veterinary Medicine, University of Baghdad, Iraq

*Dr Mohammed Dakheel's e-mail: m.m.dakheel@covm.uobaghdad.edu.iq

${ }^{2}$ Electron Microscopy Laboratory, School of Chemistry, Food and Pharmacy, University of Reading, Reading RG6 6AP, U.K.

${ }^{3}$ Department of Food and Nutritional Sciences, University of Reading, Reading RG6 6AP, UK.

${ }^{4}$ School of Agriculture, Policy and Development, University of Reading, Reading RG6 6AT, UK.

*Dr Caroline Rymer's e-mail: c.rymer@ reading.ac.uk

\begin{abstract}
Two different types of condensed tannins (CTs), which were extracted and purified from tilia (Tilia L.) and black locust (Robinia pseudoacacia), were studied and tested against two kinds of bacteria, including Gram-negative and Grampositive, avian pathogenic E. coli (APEC) and Staphylococcus epidermidis (S. epidermidis) respectively, by minimal bactericidal concentrations (MBCs) and scanning electron microscopy (SEM).
\end{abstract}

Both CT extracts were significantly effective $(P \leq 0.05)$ at MBCs of $5-10 \mathrm{mg}$ $\mathrm{CT} / \mathrm{ml}$ against APEC (Gram-negative), and at $1.25-5 \mathrm{mg} \mathrm{CT} / \mathrm{ml}$ on S. epidermidis (Gram-positive). This indicated that the CTs were more potent against the Grampositive than the Gram-negative bacteria. Further, SEM revealed that CTs caused mainly morphological deformations of the bacterial cells and some conjoined cell growth.

Keywords: Condensed tannins, avian pathogenic Escherichia coli, Staphylococcus epidermidis, minimal bactericidal concentrations, scanning electron microscopy.

\section{Introduction}

Opportunistic pathogens, such as Escherichia coli and Staphylococcus epidermidis have become the most important bacteria that cause nosocomial infections (Dho-Moulin and Fairbrother 1999; Vuong and Otto 2002) such as 
catheter-associated urinary tract infection (Gad et al. 2009). Their pathogenicity is mainly due to their ability to form biofilms on different surfaces, where the biofilm protects the bacteria from the immune system, which in turn makes it difficult to eradicate the infections (Rupp and Fey 2010; Shao et al. 2015) and the presence of certain virulence factors. Although the bacteria, which exist in/on the host body, are known as normal microbiota, only certain bacteria possess specific virulence attributes, such as APEC in chickens and $S$. epidermidis in humans. These microbes are mostly associated with other infections, principally of the systemic infections, and result in several diseases which are responsible for severe economic losses; these diseases were related to Staphylococcus aureus infection (Carson et al. 2002).

Given the increasing prevalence of antimicrobial resistance to synthetic drugs and the need to use less antibiotics in animal production, there is a considerable interest in using herbal products to control pathogenic microorganisms (Smith et al. 2007). Many plants are rich sources of bioactive natural products, such as essential oils, saponins and tannins, which may be suitable as feed additives in commercial feeding situations and possess antimicrobial properties (Scalbert 1991; Doss et al. 2009; Kuljanabhagavad and Wink 2009; Alwan 2013; Kuljanabhagavad et al. 2018). There are probably several mechanisms involved in tannin toxicity against different microorganisms; these mechanisms include using different concentrations of tannin extracts, from grape seeds, and act as antioxidant agents on Eimeria infection (Wang et al. 2008); nonetheless, tannins showed the capability on interacting with membranes, cell walls and extracellular proteins (Scalbert 1991; Maisak et al. 2013). Our recent research, which used optical density measurements, showed that CTs interfered with biofilm formation and motility of avian pathogenic Escherichia coli, particularly if the CTs were rich in prodelphinidins (Dakheel et al. 2019). Thus, the present study now reports SEM experiments to investigate CT effects on bacterial cells. and that some of these observations could have resulted from effects on bacterial cell size.

\section{Materials and methods}

\section{CT extraction and purification}

Two plant materials, including tilia (Tilia L.) and black locust (Robinia pseudoacacia), were extracted and purified by column chromatography, which is 
called Sephadex LH-20 and described by (Brown et al. 2017). The potential compositions of tilia were rich-PC (approximately $950 \mathrm{mg} / \mathrm{g}$ ), black locust was rich$\mathrm{PD}$, which recorded $740 \mathrm{mg} / \mathrm{g}$; however, the CT contents in both extracts were concentrated up to 900 of CT mg per $1000 \mathrm{~g}$ extract, as reported by (Dakheel 2018). Thus, tilia contains rich-PC and black locust includes rich-PD.

\section{Bacterial strains}

The two strains that were used for this study were provided by Fatemah AlKandari from the Food Microbial Sciences Unit (FMSU) in the Department of Food and Nutritional Sciences at the University of Reading, and the bacterial strain was an Avian Pathogenic Escherichia coli (APEC). The second bacterial strain (LAB strain), which provided by Amjed Al-Soltan from the Microbiological Laboratory of the School of Biological Sciences, University of Reading; this was Staphylococcus epidermidis (Gram-positive). These strains were maintained at $-80{ }^{\circ} \mathrm{C}$ and stored in sterile glycerol that was mixed with Luria-Bertani broth (LB) (Alkandari 2018).

\section{Determination of MBCs of the bacterial strains}

This assay was performed by a microtiter broth dilution method, as described by (Sheng et al. 2016). A total of $130 \mu \mathrm{l}$ from each concentration of the CTs, which were diluted into sterile LB broth, which was added to each well of a sterile 96 well microtiter plate (U-bottom). A $20 \mu \mathrm{l}$ volume of freshly prepared standard numbers of cells were added in different plates for each experiment, respectively. This suspension was inoculated into the wells of 96 -well plates in the presence of CTs of different concentrations $(0,10,5,2.5,1.25$ and $0.63 \mathrm{mg} / \mathrm{ml})$ and their incubation was at $37^{\circ} \mathrm{C}$ for $18 \mathrm{~h}$ before being read. For every experiment, sterile LB broth was used as a negative control and bacterial suspension with the LB broth was included as a positive control.

In order to test for the survival of bacteria after overnight growth, a $10 \mu \mathrm{l}$ sample from each well was inoculated aseptically onto LB agar and the Petri dishes were incubated at $37^{\circ} \mathrm{C}$ for $18 \mathrm{~h}$. Bacterial colonies were counted. For the purpose of this study, the MBC is defined as the lowest concentration of an antibacterial agent required to kill and prevent bacterial growth over a somewhat extended period. All 
experiments were carried out in triplicate and this experiment has been repeated three times.

\section{Determination of morphological changes of the bacterial strains by SEM}

Bacterial suspensions of APEC and $S$. epidermidis were prepared after overnight incubation in $\mathrm{LB}$ medium at $37^{\circ} \mathrm{C}$. This suspension was mixed with different concentrations of CT fractionations $(10.0$ and $1.25 \mathrm{mg} / \mathrm{ml}$ ) added to the bacterial suspension and incubated in a rotary shaker set at $100 \mathrm{rpm}$ and $37^{\circ} \mathrm{C}$ for 5 hours for APEC or without shaking at $37^{\circ} \mathrm{C}$ for 5 hours as well for $S$. epidermidis. Untreated bacterial controls were grown in standard LB medium without CTs. This protocol followed the methods of Kaya et al. (2008) to observe the bacteria by SEM.

Afterwards, the bacterial cells were harvested by centrifugation at $13000 \mathrm{xg}$ for 2 minutes and washed twice by resuspending in phosphate buffer saline (PBS). Then $200 \mu \mathrm{l}$ of each suspension was applied to a poly-L-lysine-coated glass coverslip for 15 minutes. The adhered cells were fixed in $1 \mathrm{ml}$ of $2.5 \%$ glutaraldehyde at $\mathrm{pH} 7.2$ for 20 minutes with gentle agitation.

These specimens were then rinsed with distilled water for 10 minutes, then the specimens were taken through an ethanol dehydration cycle consisting of $10 \mathrm{~min}$ in each of the following solutions, 30\%, 50\%; $70 \%, 90 \%$ and $100 \% \mathrm{v} / \mathrm{v}$, ethanol/water) and incubated for 10 minutes, except for samples in $(100 \%$; v/v) ethanol aqueous solution, which were left for an hour. These specimens were, finally, dried in the critical point dryer (vacuum environment) and sputter-coated with a thin layer of gold which made the specimens surfaces electrically conductive for SEM analysis. Then these specimens were observed with a field emission SEM.

\section{Results and discussion}

\section{Determination of MBCs of CTs on the bacterial strains}

A microtiter broth dilution and plate counting method were used to determine the MBCs of CTs on APEC (as Gram-negative) and S. epidermidis (as Grampositive). These results showed that CTs inhibited both APEC and S. epidermidis at different concentrations; MBCs were between $10-1.25 \mathrm{mg} / \mathrm{ml}$, respectively. Thus, the observations showed that MBCs of APEC were higher than for $S$. epidermidis, 
which could be explained to some extent by the presence of negatively charged lipopolysaccharide in APEC (Smith et al. 2007) given the differences in their cell wall structure.

The data generated by following the cell density using optical density (OD600) after inoculating LB broth with bacteria and CTs of various concentrations generally supported the findings of the MBC method. For instance, CTs of black locust and tilia extracts gave different MBC values $(10-5 \mathrm{mg} / \mathrm{ml})$ by the micro-dilution plating method (Table 1). Our previous study based on optical density measurements found that CTs modified the growth of pathogenic bacteria (Dakheel et al. 2019); however, this technique is not suitable for assessing whether some of the effects were due to changes in bacterial cell size. Therefore, the present study now reports scanning electron microscopy experiments to investigate CT effects on bacterial cells.

\section{Scanning Electron Microscope (SEM) for the bacterial strains}

The SEM study showed that both CT extracts could disrupt cell structures and destabilise them. The bacterial cells of both microbes had undergone some distinct morphological alterations. In order to further our understanding of the mode of action of CT on bacterial growth, SEM was performed for APEC and S. epidermidis that had been grown in LB medium. Changes in SEM characteristics were observed when both microbes were grown in the presence of CTs.

Figures from 1 to 4 show different SEM micrographs of the untreated (as control) and treated bacterial cells at different concentrations of CT compositions; i.e. PD extracted from black locust and PC from tilia. Controls, named letter $(A)$ in each figure, which showed the smooth surfaces of typical cells of these bacteria. However, letters (B, C, D, E and F/ in each figure) illustrated the SEM micrographs of bacterial cells that were treated with either black locust CT (high PD) or treated with CT from tilia extract (high PC). The same system was applied to the bacterial cells of $S$. epidermidis.

Based on this result, the appearance of the specimens at various CT concentrations was compared with controls. Further, the figures revealed the normal cell structures and shapes on typical cells and smooth surfaces compared to treated groups. However, the APEC cells seemed to have totally disappeared or collapsed 
when the cells were visible, especially at high CT concentrations of $5 \mathrm{mg} / \mathrm{ml}$ (Figure 1 and 2/ B-C); it was observed that the treated cells were damaged. The effects of CTs on the morphology of these bacteria also implicate the cell wall probably as a target of tannin toxicity. In contrast, a larger number of surviving cells were observed (Figure 1 and 2/ E-F) when low concentrations (1.25 and $0.6 \mathrm{mg} / \mathrm{ml}$ ) of CTs were added, but these cells had become stuck together leading to alteration and distortion and had lost their original shape as compared to the control cells (O'Donovan and Brookeer 2001). One unanticipated finding was that CTs showed an impact on the binary fission of these cells and preventing the division of single cells into two daughter cells. It is possible to hypothesise that these conditions are less likely to occur in controls.

Conversely, the $S$. epidermidis cells started to show multiple defects and shrunken cells (Figure 3 and 4). These bacterial cells seemed to be totally deformed and many collapsed cells were seen at all concentrations. These bacterial cells had, thus, also lost their original shape as compared to the control cells. In the present investigation, $S$. epidermidis cells were killed by a high CT concentration, whereas medium and low concentrations caused severe damage and whole-cell lysis for some cells. This finding was related to the impact of CTs on these bacteria, especially on their cells. It has been suggested previously that any interactions with the hydrophobic cell surface of microbes can play a critical role in the antimicrobial effect on Staphylococci strains (Carson et al. 2002). These findings matched previous results (Darah et al. 2013) that also reported morphological changes when some phytochemicals such as flavonoids, terbinoids and tannins attacked the cell membrane and worked as antimicrobial agents. It is likely that the CTs adhered to bacterial cells then they tried to survive by forming the biofilm (Dakheel et al. 2019). Clearly, any disruption of cell walls will impact on bacterial growth (Sheng et al. 2016). Given these findings, it may be postulated that CTs disrupt cell structure and function including septum formation which is essential for cellular division and population growth (Alkandari 2018; Dakheel 2018).

However, it is thought that CTs have a greater antimicrobial effect on Grampositive than on Gram-negative bacteria because the latter contains an extra outer membrane, which includes lipids, phospholipids and lipopolysaccharide that are located in the inner and outer layers; hence, these membranes can act as a barrier 
that hinders the movement of foreign substances into the bacterial cell (Lewu et al. 2006; Brown et al. 2017). Nonetheless, further studies are required to identify how these CT extracts impact on other bacteria in vitro and in vivo.

\section{Conclusion}

In conclusion, this study confirmed that there were significant antibacterial effects on the Gram-positive and Gram-negative bacteria. Relatively, high CT concentrations $(10-5 \mathrm{mg} / \mathrm{ml})$ were used and showed several antimicrobial activities against APEC by affecting MBCs. However, low concentrations of CTs (1.25 - 0.6 $\mathrm{mg} / \mathrm{ml}$ ), had either a weak effect as on $S$. epidermidis or no impact as an antimicrobial agent, especially on APEC. SEM micrographs revealed that shrinkage of the bacterial cell was apparent in CT-treated cells compared to the untreated groups of both microbes. Additionally, CTs affected the binary fission of the bacterial cells, which is an important process in bacterial reproduction by the division a single cell into two daughter cells.

In general, these SEM results confirm that different CT extracts in high concentrations (both PD-rich and PC-rich) possess antibacterial activity, and this supports the MBC results. However, the lowest concentrations of CT from tilia extract showed less activity on APEC. Thus, further investigations will need to determine the effects of CT compositions by Transmission electron microscopy (TEM) to investigate the dysfunction and apparent loss of turgidity and leakage of the cytoplasm from the bacterial cells.

\section{Acknowledgements}

The authors would like to thank the Ministry of Higher Education and Scientific Research and Veterinary Medicine College at Baghdad University/ Iraq, for supporting this study. Further, appreciations go to the School of Agriculture, Policy and Development, and the School of Chemistry, Food and Pharmacy at the University of Reading for their help to achieve this research study.

\section{Conflicts of Interest}

The authors declare that they have no conflicts of interest.

\section{References}


Alkandari, F. A. H. (2018) Characterisation of Escherichia coli in poultry and their interaction with phytochemicals. PhD Thesis, University of Reading, http://centaur.reading.ac.uk/76613/

Alwan, M. (2013) Histopathological Study for the Effect of Ethanolic Extract of Sonchus Oleraceus on Escherichia Coli Bacteria in Mice. Iraqi J Vet Med, 37, 167-174.

Brown, R. H., Mueller-Harvey, I., Zeller, W. E., Reinhardt, L., Stringano, E., Gea, A., Drake, C., Ropiak, H. M., Fryganas, C., Ramsay, A., and Hardcastle, E. E. (2017) Facile Purification of Milligram to Gram Quantities of Condensed Tannins According to Mean Degree of Polymerization and Flavan-3-ol Subunit Composition. J Agric Food Chem, 65, 8072-8082.

Carson, C. F., Mee, B. J., and Riley, T. V. (2002) Mechanism of action of Melaleuca alternifolia (tea tree) oil on Staphylococcus aureus determined by time-kill, lysis, leakage, and salt tolerance assays and electron microscopy. Antimicrob Agents Chemother, 46, 1914-20.

Dakheel, M. M. (2018) The influence of condensed tannin extracts on gut health in chickens. PhD thesis, University of Reading, http://centaur.reading.ac.uk/80653/

Dakheel, M.M., Alkandari, F.A., Mueller-Harvey, I., Woodward, M.J. and Rymer, C. (2020) Antimicrobial in vitro activities of condensed tannin extracts on avian pathogenic Escherichia coli. Lett Appl Microbiol., 70, 165--172.

Darah, I., Lim, S. H., and Nithianantham, K. (2013) Effects of Methanol Extract of Wedelia Chinensis Osbeck (Asteraceae) Leaves against Pathogenic Bacteria with Emphasise on Bacillus cereus. Indian J Pharm Sci, 75, 533-9.

Dho-Moulin M., and Fairbrother J. M. (1999) Avian pathogenic Escherichia coli (APEC). Veterinary Research, BioMed Central, 30, 299-316.

Doss, A., Mubarack, H. M., and Dhanabalan, R. (2009) Antibacterial activity of tannins from the leaves of Solanum trilobatum. Linn. Indian J Sci Technol, 2, 41-43.

Gad, G.F.M., El-feky, M.A., El-rehewy, M.S., Hassan, M.A., Abolella, H. and Abd Elbaky, R. M. (2009) Detection of icaA, icaD genes and biofilm production by Staphylococcus aureus and Staphylococcus epidermidis isolated from urinary tract catheterized patients. J. Infect. Dev. Ctries., 3, 342-351. 
Kaya, I., Yigit, N., and Benli, M. (2008) Antimicrobial activity of various extracts of Ocimum basilicum $\mathrm{L}$. and observation of the inhibition effect on bacterial cells by use of scanning electron microscopy. AJTCAM, 5, 363-369.

Kuljanabhagavad, T., Sriubolmas, N., and Ruangrungsi, N. (2018) Chemical Composition and Antimicrobial Activity of the Essential Oil from Heracleum Siamicum. J. Health Res, 24, 55-60.

Kuljanabhagavad, T., and Wink, M. (2009) Biological activities and chemistry of saponins from Chenopodium quinoa Willd. Phytochem Rev, 8, 473.

Lewu, F. B., Grierson, D. S., and Afolayan, A. J. (2006) Extracts from Pelargonium sidoides inhibit the growth of bacteria and fungi. Pharm. Biol., 44, 279-282.

Maisak, H., Jantrakajorn, S., Lukkana, M., and Wongtavatchai, J. (2013) Antibacterial Activity of Tannin from Sweet Chestnut Wood Against Aeromonas and Streptococcal Pathogens of Tilapia (Oreochromis niloticus). Thai J Vet Med, 43, 105-111.

O'Donovan L. and Brookeer J.D., (2001) Effect of hydrolysable and condensed tannins on growth, morphology and metabolism of Streptococcus gallolyticus (S. caprinus) and Streptococcus bovis. Microbiol, 147, 1025-1033.

Rupp M. E., and Fey P. D. (2010) Staphylococcus epidermidis and Other Coagulase-Negative Staphylococci. in Principles and Practice of Infectious Diseases, G. L. Mandell, J. E. Bennett, and R. Dolin, (Eighth Edition), 2. Churchill Livingstone, Philadelphia, PA., USA.

Scalbert, A. (1991) Antimicrobial Properties of Tannins. Phytochemistry, 30, 38753883.

Shao, D., Li, J., Li, J., Tang, R., Liu, L., Shi, J., Huang, Q., and Yang, H. (2015) Inhibition of Gallic Acid on the Growth and Biofilm Formation of Escherichia coli and Streptococcus mutans. J Food Sci, 80, M1299-305.

Sheng, L., Olsen, S. A., Hu, J., Yue, W., Means, W. J., and Zhu, M. J. (2016) Inhibitory effects of grape seed extract on growth, quorum sensing, and virulence factors of CDC "top-six" non-O157 Shiga toxin-producing E. coli. Int J Food Microbiol, 229, 24-32.

Smith, J. L., Drum, D. J., Dai, Y., Kim, J. M., Sanchez, S., Maurer, J. J., Hofacre, C. L., and Lee, M. D. (2007) Impact of antimicrobial usage on antimicrobial resistance in commensal Escherichia coli strains colonizing broiler chickens. Appl Environ Microbiol, 73, 1404-14. 
Vuong, C., Otto, M. (2002) Staphylococcus epidermidis infections, Microbes and Infection., 4, 481-489.

Wang, M. L., Suo, X., Gu, J. H., Zhang, W. W., Fang, Q., and Wang, X. (2008) Influence of grape seed proanthocyanidin extract in broiler chickens: effect on chicken coccidiosis and antioxidant status. Poult Sci, 87, 2273-80. 